\title{
SUPERVISION OF POST-GRADUATE STUDENTS IN HIGHER EDUCATION
}

\author{
Van Rensburg GH, Mayers P \& Roets L
}

\begin{abstract}
Knowledge transfer is an inevitable process in higher education where research outputs are largely associated with the production of Masters' and Doctoral graduates. The supervision of postgraduate students at universities is therefore one of the core responsibilities of academics and is considered a measure of academic output. Supervision not only transfers research and related skills, but is also an intensive and interconnected form of educator-student engagement. The role of the supervisor in providing a supportive, constructive and engaged supervision process is important in the development of next generation practitioners who have the correct educational and skills mix to fulfil the future needs of the profession. The underlying principle of student support during supervision is that an experienced supervisor will be able to move through the learning processes with the student as this becomes appropriate. As the student gains competence in the basic skills of conducting research in a particular field of study, he or she will move to a deeper understanding of the nature and reality of that field. Research and, ultimately, high quality supervision of students, plays a pivotal role in the scholarship of discovery and the development of evidence-based practice.
\end{abstract}

\section{Keywords:}

student support, supervision, supervisor

\section{Introduction and background}

We live in an environment and culture in which the provision of quality health care is expected from healthcare professionals in both the private and public sectors. An implication of this expectation is that decisions, including those made by nurses and midwives, should be justified by scientific evidence (McNicholl et al., 2008). Research, and therefore ultimately quality supervision of students, plays a pivotal role in the scholarship of discovery and the development of evidence-based practice.

Creating, transferring and managing knowledge has become a central issue in the knowledge economy with its competitive environment, creating increased pressure on higher education institutions to enhance postgraduate research outputs. A fundamental tenet of the National Plan for Higher Education is the production of Master's and Doctoral graduates at South African universities (Department of Education, 2001). A core responsibility of university academics is supervision of postgraduate students and the throughput rate of students is a measure of output. De Gruchy and Holness (2007) describe graduate supervision as being "situated the interface of teaching and research ... having to do with the transference of research and related skills".

The quality of postgraduate students is a primary focus for universities, as reflected in institutional audits (Mouton, 2007). Quality comprises two key aspects: "the quality of the 
supervisory process (by supervisors) and the quality of the research output (by students)" (Lessing \& Schulze, 2003). Concomitant with the challenges of ensuring increased throughput and quality output is the transformation of universities into businesses where the subsidy formulas have changed and greater emphasis is placed on the throughput rates of students (Lessing \& Schulze, 2003; Lessing \& Lessing, 2004).

The increase in the number of universities worldwide, the expansion of student numbers in higher education, the multiplication and flexibility of degrees and subject choices are set against the context of a rapidly changing economy and employment market (Rae, 2007: 606). Increasingly, the employment sector is demanding graduates with technological skills and ability to apply knowledge (McCallin \& Nayar, 2012). Universities are faced with the imperative of producing competent graduates and postgraduates, yet also have to provide access and support for students who may not possess the foundational skills necessary for postgraduate work as a consequence of a lack of access to critical basic education (Lessing \& Schulze, 2003; Lessing \& Lessing, 2004).

In South Africa, an increasing number of graduates is returning to universities for postgraduate study, affecting the supervisor-student ratio, thus impacting on student support and supervision. This is a world-wide phenomenon and Taylor (2002) has argued that this represents a transformation in higher education access, from the few elite to a mass system. The students are diverse in terms of age, language, cultural socio-economic status and educational background. This diversity poses challenges for the traditional supervisor-student process of supervision. New options are being explored to provide support and engaged communication (Pillay \& Balfour, 2011; Watts, 2010; White \& Coetzee, 2014) and the use of technology is replacing much of the traditional, personal one-to-one supervision (De Beer \& Mason, 2009; Unwin, 2007; White \& Coetzee, 2014; Winberg, 2014).

Supervision requires professional commitment, as it is an intensive form of educator-student engagement. The multiple layers of the supervisor-student relationship need to be recognised and engaged with in order for a successful outcome to be achieved. In particular, Halse and Malfroy (2010) argue that doctoral supervision requires specialised professional activities that comprise five features: the learning agreement, habits of mind, intellectual expertise, technicalities and contextual expertise.

Bitzer (2011) further argues that, while there have been a number of studies that make the case for more effective postgraduate supervision and the need for student commitment and identity development, there has been less emphasis on the institution or the university and its role in the production of knowledge and wisdom. Postgraduate study is more than just the production of knowledge. It also entails the development of a new scholar in a specific profession or work environment. Referring to doctoral supervision, Petersen (2007) affirms that the supervisory relationship "constitutes a negotiation of boundaries around what it means to undertake research that is recognisable as 'academic' or 'scientific' ...". These boundaries relate to power relationships, independence versus dependence and the 'becoming' of a new member of the academy. Effective supervision depends not only on the competence of the supervisor and the 
commitment of the student, but also on the nature of the relationship that exists at the centre of the supervisory process (Emilsson \& Johnsson, 2007).

Regardless of the nature of the discipline, theoretical basis or orientation, the aim of supervision is to increase the knowledge and competence of the practitioner (Emilsson \& Johnsson, 2007). In health sciences, there is a demand for skilled academic practitioners, whether practice, education or research-focused (Cleary, Hunt, \& Jackson, 2011). Students entering the university have high expectations for the achievement of a goal - that of the higher degree and the possibilities that this will open doors for future careers. Stakeholders require evidence about the outcomes of higher degrees with respect to the leadership and management skills that graduates will bring back to the clinical healthcare environment, as well as their educational capability, research expertise and ability to utilise evidence in practice (Cleary et al., 2011; Drennan, 2008).

Wisker (2005) states that "research supervision plays a key role in higher education in empowering students to become researchers". Good practice standards for postgraduate research degree programmes with respect to research supervision recommend that the following components are attended to: institutional arrangements; research environment; selection, admission, enrolment and induction of students; supervisory arrangements; initial review and subsequent progress; development of research and other skills; feedback mechanisms; and appeals and complaints (Metcalfe, Thompson, \& Green, 2002).

In this paper, the focus is on the supervision of postgraduate students in higher education

Research supervision has particular relevance for the development of contextual, evidencebased and relevant knowledge and leadership in order to improve health care (Ketefian, Davidson, Daly, Chang, \& Srisuphan, 2005; Severinsson, 2012). The value benefits of research supervision are improvements in the quality of academic education and the quality of service (Severinsson, 2010).

The role of the supervisor in providing a supportive, constructive and engaged supervision process is important to ensure that the future generation of students have the right educational and skills mix to fulfil the needs of the profession (Cleary et al., 2011). The role of a postgraduate supervisor is complex, as outlined by de Gruchy and Holness (2007), who identify four keys areas of supervision:

- to oversee - advise on the management of a project; guide; ensure scientific quality;

- to teach the craft of research;

- to be a role model;

- to provide a supportive relationship with three components: intellectual, technical/strategic and emotional.

Supervision, therefore, is complex and the process needs to be understood.

\section{The supervision process}


The supervision process starts with the selection of postgraduate students and extends to how the research conducted (proposed topic) relates to practice and the working environment.

Appropriate initial selection of students for the postgraduate research programmes is important, especially for the research master's and doctoral degrees. Initial selection should be guided by the institutional policies, and potential students should be fully informed of the commitments that the programme requires, with respect to time, degree of enterprise initiative and intellectual autonomy (Thompson, Kirkman, Watson, \& Stewart, 2005).

Supervisors should have appropriate research qualifications and experience. Experienced supervisors should work with less experienced academics to support their own development as supervisors. There is a good argument for having two supervisors. The benefits of this for students are: different perspectives are brought to the supervisory process, there is a complementarity of approach, content and methodological expertise; and, for novice supervisors, the experience of 'learning on the job' (Thompson et al., 2005).

The supervisory agreement should be negotiated within the framework of institutional requirements. Essential aspects of this agreement include: accessibility of the supervisor; regularity of meetings (whether face-to-face or via other media); preparation for such meetings and the time-line for submission of written drafts; responsibility for keeping a record of meetings; expected targets and timetable; assistance from other sources such as writing centres, librarians and computer literacy programmes.

The supervisory agreement is, however, affected by various factors. Many students enter the postgraduate education environment without sufficient knowledge of research methods (Lessing \& Schulze, 2003) or academic literacy (Singh, 2011; Strauss, 2012), and have little prior knowledge or expectations of roles and responsibilities in this regard (Lee, 2010). They may not be able to progress through the postgraduate programme without significant development of the required skills and adequate support. Students also enter the postgraduate experience with different cultural backgrounds and learning styles (Wisker, 2005). Ngcongo (2000) and Kiani and Jumani (2010), argue that supervision involves not only the facilitation of research skills capacity, but also the development of the students' self-esteem and guidance in order for them to become independent researchers with the ability to conceptualise and think critically.

Supervision requires a concern that extends beyond the academic. The supervisor needs to show concern and commitment, not only to the student's intellectual development and discovery of their academic potential, but also to the development of an understanding of the student as a whole person with other roles and responsibilities which may include family, work and other non-academic activities. This understanding will enable the supervisor to assist the student to maintain a balance, as it is often the demands of non-academic nature that will influence the successful completion of the degree (James \& Baldwin, 1999). Supervision requires a shared responsibility between the supervisor and student, making the supervisorstudent relationship an emotional association. Both the supervisor and student simultaneously lead and learn, and both depend on each other for emotional as well as other support (Van Laren et al., 2014). This sharing of the process highlights the need for a nurturing and protective 
partnership. This obviously depends heavily on the relationship created between the supervisor and student. This partnership in turn is influenced by the personal and professional characteristics of both supervisor and student.

The supervisor's role entails guiding students towards independence, and thus the supervisor should maintain a balance in feedback between giving too much or too little direction (Kiani \& Jumani, 2010: 416). She or he also needs to coach students to improve their written work (Wang \& Lee, 2011: 102). Supervisors need to take responsibility for making suggestions and provide options for change and improvement of the supervised materials, in such a way that the student takes the responsibility for the improvement and the academic development.

\section{Supervisor characteristics}

The supervisor facilitates a process that is described as comprising "intellectual, methodological and pastoral elements" (Watts, 2010), all of which are key supervisory characteristics. The relative significance of each of these elements changes during the course of the research process. Supervisors are expected to be nurturing and supportive, friendly, patient, honest, trustworthy, culturally sensitive, understanding, open, approachable, flexible, tolerant and unbiased (De Beer \& Mason, 2009, Coetzer, 2013; Kiley, 2011; Maxwell \& Smyth, 2010). They also need to be knowledgeable about research, have experience in supervision and share an interest in the student's topic (Lee, 2010). To have all these characteristics embedded in one specific person is a daunting task. In addition to the above, students expect to have a good relationship with their supervisors. Student satisfaction with supervision and degree completion are very closely linked, and the relationship with the supervisor therefore becomes the key to student's success (Wolff, 2010: 229). Many students are far more concerned about completing their research projects and obtaining a degree than about the scientific value of what they are working on (Paretti, McNair \& Holloway-Attaway, 2007; Van Vuuren, 2013). This attitude might have a negative impact on the students' perception of what a good relationship implies and what they can really expect from supervisors.

James and Baldwin (1999) provide a useful framework for good practice in postgraduate supervision. Eleven practices that relate to the characteristics of an effective supervisor are summarised:

- Ensure the partnership is right for the project.

- Get to know students and carefully assess their needs.

- Establish reasonable, agreed upon expectations.

- Work with students to establish a strong conceptual structure and research plan.

- Encourage students to publish their work early in their academic life and often.

- Initiate regular contact and provide high-quality feedback.

- Get students involved in the life of the department.

- Inspire and motivate students.

- Help if academic and personal crises crop up.

- Take an active interest in students' future careers. 
- Carefully monitor the final production and presentation of the research (James and Baldwin, 1999)

Using the above framework as a guide when supervising a student could equip the supervisor with direction in terms of the supervision process, supervision agreement and student support.

\section{Student support}

Student support during postgraduate supervision can be described as 'travelling' and 'growing' processes that facilitate learning. Facilitation suggests the notion of making an experience easier for someone else (Van Laren et al, 2014). To address the processes in the learning experience, reflective practices could serve as support for developing knowledge and skills. Knowledge is thus created through the pedagogical processes of enquiry.

Different types of student support can be identified. These include academic, (including methodological and writing skills), emotional and structural support.

\section{Academic support}

The underlying premise of student support during supervision is that an experienced supervisor will be able to move through the learning processes related to knowledge and skills with the student as it becomes appropriate. As the student gains competence in the basic skills of conducting research in a particular field of study, he or she will move to a deeper understanding of the nature and reality of that field.

Lee and Murray (2013) propose a framework for supervising students and supporting them on five levels. The functional level (level 1) requires a student to progress rationally through the tasks associated with research. On the second level (enculturation) students are encouraged to become members of the subject/specialty community, where role-modelling and apprenticeship/internship/education become evident. The focus here is on cognitive apprenticeship (McCallin \& Nayar, 2012). At the third level (critical thinking), students are encouraged through constant inquiry to analyse their work. This level is characterised by enquiry-based learning. During level four, students are emancipated as they reflect on their work and reframe their thoughts with the support of the supervisor as mentor. Level five is reached when the student develops a quality relationship within the process of research and supervision, and becomes motivated and inspired. At this level the supervisor-student relationship has reached a team approach type of support.

Student support and student development often opens an interesting discourse. Students can only be effectively supported and developed during the supervision process if they are ready to apply themselves to postgraduate studies. A question arises as to how student support should be constructed. Leading the student to become an 'autonomous learner' or 'autonomous researcher (postgraduate student)' is a neutral approach where the context is not crucial, but rather the factors inherent to the individual (motivation, intelligence, interests and aptitude) are. The construction of student support from a social perspective would focus on the social contexts within which the students are supervised. Learning how to learn, or do research, 
implies taking up a position on knowledge and knowing, where the learning (or doing research) requires more than technical skills. It involves values, attitudes and practices. For postgraduate students to be successful, they must acquire new understandings of knowledge, as well as new practices or behaviours which facilitate learning. These new practices and behaviours include understanding knowledge construction and the role of the researcher in knowledge development within the societal context.

\section{Writing support}

Any research report requires sound academic writing (Wolff, 2010). Based on the framework for supervising students as proposed by Lee and Murray (2013), the student will first have to understand the principles of academic writing and acquire the skills though simple tasks and experiences before those of scientific writing.

Writing about their research causes significant anxiety in students. Many students are unable to synthesise and think conceptually, structure their writing or write at an appropriate level. Academic writing, particularly for a non-first-language English-speaking student, is challenging. The skill of academic writing requires more than just a command of the structure and vocabulary of the language. It is more aligned to the coherence of the student's thought processes.

Although the supervisor as facilitator engages in developing students to be able to write academically, the concern is always that the supervisor should not be a 'proofreader' by checking spelling, grammar, syntax and helping students to formulate ideas (Lee \& Murray, 2013). The question of whose work it is may then be asked. The role of the supervisor should rather be one of supporting the student to be emancipated by thinking critically about the work in progress.

Through feedback and assessment the supervisor is able to identify the student's strengths and weaknesses in writing. Criteria for writing through which students learn to construct and deconstruct arguments and identify gaps and weaknesses in their logic will encourage conceptual mapping. As they develop their writing skills, students should be able to debate approaches to an argument as well as the content and embrace criticism. The outcome will be rhetorical competence that will allow a student to write scientifically and act as an author.

\section{Emotional support}

A key element of the supervision is the supervisor-student relationship. This relationship is influenced by academic as well as socio-cultural factors. The challenge for the supervisor is to manage the diverse aspects of the relationship in such a way that the outcome for both parties is positive. There should be mutual respect for each others' views, an openness to explore difficulties and to engage in dialogue which promotes effective learning. Issues such as the balance of power (Manathunga, 2007), gender, cultural background and expectations, and communication patterns (Hodza, 2007) need to be understood and engaged with appropriately. The supervisor needs to be interested in the student as a person and demonstrate a caring commitment, which enables the student to explore new ideas, interrogate existing ones and develop competence in the methodology and field of study (Gill \& Burnard, 2008; Hodza, 2007). 


\section{Structural support}

Although the institution and department share the responsibility for providing a supportive framework in which students can engage with their studies, supervisors also have a role to play in ensuring that students are aware and make use of other resources. These include: funding opportunities, training courses, such as library search skills or specific research methods, networking opportunities, attendance and presentation at postgraduate seminars and conferences relevant to their research and encouraging research support groups among students (de Gruchy \& Holness, 2007).

\section{Supervisor-student communication}

One of the key elements in the supervisor-student relationship is communication, and more specifically feedback on submitted work related to the research project.

\section{Constructive feedback}

Communication and feedback, whether in writing, oral, online or in combination, can only be effective if the message that the supervisor wants to convey corresponds directly with how the student perceives that message. In a diverse South African context, feedback and communication between student and supervisor may be in a language that is in neither the person's mother tongue (Bell, 2007) and can very easily be misinterpreted (Batane, 2010). Good communication skills are therefore essential in order to engage with students on a face-to-face basis, as well as within the online environment (Betts, 2009).

Good quality feedback to students is essential (McCallin \& Nayar, 2012; Severinsson, 2012) and should alert the students to the areas in their work that need improvement. This should, however, also nurture the student by identifying and praising positive features of the work, and providing constructive advice on how to improve in the areas of weakness (Wolff, 2010). Critical and constructive feedback should be "delivered and received in a manner that contributes to an educational relationship" (Li \& Seale, 2007) without provoking resentment, resistance, defensiveness, hurt feelings, shame or a sense of failure. It should be non-judgemental, appreciative of good work, as well as identifying problem areas, and provide options for change (Hamid \& Mahmood, 2010).

Because of the differences in expectations between supervisors and students (Coetzer, 2013; Van Vuuren, 2013) constructive feedback can be perceived differently. The relationship between student and supervisor influences how students perceive feedback and therefore the affective relationship between supervisor and student is important (Clynes \& Raftery, 2008).

Feedback should be carefully planned. Questions can be asked to encourage critical thinking, rather than simply pointing out changes which may need to be made (Forneris \& PedanMcAlphine, 2006). Examples of useful questions include:

- Why is your choice the best option as the methodology for your study?

- What literature can be used to support your statement? 
- Are you convinced that you have read the literature from the important authors pertaining to your topic?

- Are these the most recent articles/literature on the sampling technique?

Feedback to students takes the form of face-to-face and/or electronic (e.g. Skype) contact sessions, but should always be supported by written feedback.

The World Wide Web has opened the opportunity for students around the globe to embark on doctoral and master's studies at any university, resulting in many students never receiving faceto-face feedback from supervisors. There is, however, a growing consensus that an effective teaching presence can be established online (Gunter, 2007), and supervision can be done effectively without face-to-face contact.

Whether feedback is given face-to-face or via electronic media, the key to the success of feedback and its acceptance is the commitment of the supervisor to support the student (Holberg, 2008). The basic principles of constructive feedback and communication thus remain the same, although the medium might be different. In the face-to-face environment, non-verbal communication plays a very important role that is often compromised in the online environment.

In the virtual and online world, the body language of neither the supervisor nor the student is visible (Betts, 2009) and the nonverbal message can become lost in translation. Online communication skills are a very important supervisory attributes in providing appropriate feedback.

\section{Written feedback}

Skill is required to be able to provide constructive feedback on written work. Strategies for giving constructive feedback include: pitching the criticism at the student's level of understanding; depersonalising criticism and keeping it specific; grounding feedback in evidence from the written work; linking to strategies for improvement and using appropriate language in a collaborative rather than a lecturing style.

Wolff (2010) suggests that learning takes place through writing. The written word of the student gives meaning to the learning that has taken place during the research. Written feedback, as used in online communication, serves as a dialogue and quality assurance process. Before responding, the supervisor should read the student's submitted work thoroughly. The aim is to give constructive feedback that will provide intellectual expertise. Sharing expertise through written feedback could be seen in terms of reflective conversations that clarify assumptions and expectations, express feelings and dilemmas and invite students to express their own experiences (McMichael \& MacKee, 2008).

The benefit of online communication is that it is predominantly asynchronous and allows for a reflective form of communication: in other words, there is sufficient time for supervisors to reflect before sending a message (Betts, 2009). 
Non-verbal communication elements need to be approximated in an e-mail or text "emotions" like a smiling face, or a textual equivalent (-) (Prensky, 2004). This is time-consuming, but supervisors need to express emotion.

Written electronic feedback should always be carefully phrased, as there may be limited opportunity to discuss the comments, and the supervisor should conform to 'etiquette' when sending text messages or emails. Be careful of using bold text and capital letters. The following is an example of a comment that should not be used:

\section{- DO NOT USE THE SAME REFERENCE AS MOTIVATION FOR THE ENTIRE PROBLEM STATEMENT!!!!!!!}

The same comment could be made in a friendlier and more professional manner such as:

- Please do not use the same reference as motivation for the entire problem statement $(-)$

- Could you please find more references to support your problem statement $(;)$

All words have meaning, and the way in which they are written will convey intent, and that will never change (Kallos, 2014). In today's electronic age, however, the skilled online communicator should be able to communicate clearly just by the choice of words, without relying on bold type, font size, capital letters or colours. This is a relatively new, but necessary skill for the supervisor with more traditional experience.

\section{Conclusion}

The market for postgraduate education has evolved and research supervision has had to adapt (McCallin \& Nayar, 2012). Students, whether they can meet with their supervisors face- to-face, only through the electronic media, or a combination of both, need to be effectively and efficiently supervised to ensure success. Supervisors need to provide the type of supervision which ensures that students produce work of a high standard which enhances throughput rates (Kiley, 2011).

Supervision is an interconnected learning and developmental process that takes place within a relationship between the supervisor and student. Interpersonal skills to enhance the interaction have become more important, given the variety of communication platforms. As in a professional and mature relationship, both supervisor and student need to show tolerance and appreciation towards each other. Commitment grounded in honesty and responsiveness contribute to the supervision relationship as an intellectual, as well as socio-emotional, relationship. Despite the diversity of support structures available for students, effective and engaged supervision will continue to be an important componet of the postgraduate experience.

\section{References}


Batane, T. 2010. Turning to Turnitin to Fight Plagiarism among University Students. Journal of Educational Technology 13 (2): 1-15.

Bell, N.D. 2007. How native and non-native English speakers adapt to humor in intercultural interaction. International Journal of Humor Research 20 (1): 27-48.

Betts, K. 2009. Lost in translation: importance of effective communication in online education. Online Journal of Distance Learning Administration 12 (2): 1-13. University of West Georgia: Distance Education Centre. Available at: www.westga.edu distance/ojdla/summer122/betts122.html (Accessed on 8/04/2014).

Bitzer, E.M. 2011. Knowledge with wisdom in postgraduate studies and supervision: Epistemological and institutional concerns and challenges. South African Journal of Higher Education 25 (5): 855-874.

Cleary, M., Hunt, G.E., \& Jackson, D. 2011. Demystifying PhDs: A review of doctorate programs designed to fulfil the needs of the next generation of nursing professionals. Contemporary Nurse: A Journal for the Australian Nursing Profession 39 (2): 273-280.

Clynes, M.P. \& Raftery, S.E.C. 2008. Feedback: An essential element of student learning in clinical practice. Nurse Education in Practice 8: 405-411.

Coetzer, D. 2013. Nagraadse verpleegstudente se verwagtinge rakende studieleiding. Thesis for Magister Societatis Scientiae (Nursing) degree. Universiteit van die Vrystaat.

De Beer, M.. \& Mason, R.B. 2009. Using a blended approach to facilitate postgraduate supervision. Innovations in Education and Teaching International 46 (2): 213-226.

De Gruchy, J. W.. \& Holness, L. 2007. The Emerging Researcher. Nurturing passion, developing skills, producing output. Cape Town: Juta \& Co.

Department of Education. 2001. National Plan for Higher Education. Pretoria: Department of Education, South Africa.

Drennan, J. 2008. Postgraduate Research Experience Questionnaire: reliability and factor structure with Master's in Nursing graduates. Journal of Advanced Nursing 62 (4): 487-498. doi: 10.1111/j.1365-2648.2008.04619.x

Emilsson, U.M., \& Johnsson, E. 2007. Supervision of supervisors: on developing supervision in postgraduate education. Higher Education Research \& Development 26 (2): 163-179. doi: 10.1080/07294360701310797.

Forneris, S.G., \& Peden-McAlpine, C.J. 2006. Contextual learning: A reflective learning Intervention for nursing education. International Journal of Nursing Education Scholarship, 3 (1): article 17.

Gill, P., \& Burnard, P. 2008. The student-supervisor relationship in the PhD/Doctoral process. British Journal of Nursing 17 (10): 668-672.

Gunter, G. 2007. The Effects of the Impact of Instructional Immediacy on Cognition and Learning in Online Classes. International Journal of Social Sciences 2 (3): 196-202. 
Halse, C., \& Malfroy, J. 2010. Retheorizing doctoral supervision as professional work. Studies in Higher Education 35 (1): 79-92. doi: 10.1080/03075070902906798

Hamid, Y. \& Mahmood, S. 2010. Understanding constructive feedback: a commitment between teachers and students for academic and professional development. Journal of Pakistan Medical Association 60 (3): 224-227.

Hodza, F. 2007. Managing the student-supervisor relationship for successful postgraduate supervision: A sociological perspective. South African Journal of Higher Education 21 (8): 11551165.

James, R., \& Baldwin, G. 1999. Eleven practices of effective postgraduate supervisors Retrieved from

http://www.cshe.unimelb.edu.au/resources teach/teaching in practice/docs/11practices.pd $\underline{f}$

Kallos, J. 2014. Business e-mail etiquette. Large, red and bold: is this shouting too? Available at: http://www.netmanners.com (Accessed on 09/04/2014).

Ketefian, S., Davidson, P., Daly, J., Chang, E., \& Srisuphan, W. 2005. Issues and challenges in international doctoral education in nursing. Nursing \& Health Sciences 7 (3): 150-156. doi: 10.1111/j.1442-2018.2005.00240.x

Kiani, A. \& Jumani, N.B. 2010. Mentoring model for research in Higher Education in Pakistan. International Journal of Academic Research 2 (5): 414-430.

Kiley, M. 2011. Developments in research supervisor training: causes and responses. Studies in Higher Education 36 (5): 585-599.

Lee, N.J. 2010. Making research supervision work for you. Nurse Researcher 17 (2): 44-51.

Lee, A. \& Murray, R. 2013. Supervising writing: helping postgraduate students develop as researchers. Innovations in Education and Teaching International.

http://dx.doi.org/10.1080/14703297.2013.866329.

Lessing, A.C., \& Schulze, S. 2003. Postgraduate supervision: students' and supervisors' perceptions. Acta Academica 35 (3): 161-184.

Lessing, N., \& Lessing, A. C. 2004. The supervision of research for dissertations and theses. Acta Commercii 4: 73-87.

Li, S., \& Seale, C. 2007. Managing criticism in Ph.D. supervision: a qualitative case study. Studies in Higher Education 32 (4): 511-526. doi: 10.1080/03075070701476225

Manathunga, C. (2007). Supervision as mentoring: the role of power and boundary crossing. Studies in Continuing Education 29 (2): 207-221.

doi: 10.1080/01580370701424650 
McCallin, A., \& Nayar, S. 2012. Postgraduate research supervision: a critical review of current practice. Teaching in Higher Education 17 (1): 63-74.

doi: 10.1080/13562517.2011.590979.

McMichael, M.J., \& McKee, M. 2008. Research supervision: An important site of teaching. Journal of teaching in Social Work 28 (1-2): 53-70.

McNicholl, M.P., Coates, V. \& Dunne, K. 2008, Driving towards an improved research and development culture. Journal of Nursing Management 16 (3): 344-351.

Metcalfe, J., Thompson, Q., \& Green, H. 2002. Improving standards in postgraduate research degree programmes. Journal details missing here.

Mouton, J. 2007. Post-graduate studies in South Africa: Myths, misconceptions and challenges. South African Journal of Higher Education: Postgraduate Supervision 2007: Special Edition 8 (21): 1078-1090.

Ngcongo, R. 2000. Self-esteem enhancement and capacity building in the process of supervising master's students. South African Journal of Higher Education 14 (1): 211-217.

Paretti, M.C., McNair, L.D., \& Holloway-Attaway, L. 2007. Teaching technical communication in an era of distributed work: a case study of collaboration between U.S and Swedish students, Technical Communication Quarterly 16 (3): 1-13.

Petersen, E.B. 2007. Negotiating academicity: postgraduate research supervision as category boundary work. Studies in Higher Education 32 (4): 475-487. doi: 10.1080/03075070701476167.

Pillay, G., \& Balfour, R.J. 2011. Post-graduate supervision practices in South African universities in the era of democracy and educational change 1994-2004. South African Journal of Higher Education 25 (2): 358-372.

Prensky, M. 2004. The emerging online life of the digital native: what they do differently because of technology, and how they do it. Viewed 9 April 2014, www.marcprensky.com/.../Prensky-The Emerging Online Life of the Digital Native-03.pdf

Rae, D. 2007 Connecting enterprise and graduate employability: Challenges to the higher education culture and curriculum? Education and Training, 49(8/9):605-619.

Severinsson, E. 2010. Discovering the value of research supervision. Nursing \& Health Sciences 12 (4): 400-401. doi: 10.1111/j.1442-2018.2010.00565.x

Severinsson, E. 2012. Research supervision: supervisory style, research-related tasks, importance and quality - part 1. Journal of Nursing Management 20 (2): 215-223. doi: 10.1111/j.1365-2834.2011.01361.x

Singh, S. 2011. An intervention to assist students with writing their dissertations and theses. South African Journal of Higher Education 25 (5): 1020-1030.

Strauss, P. 2012. 'The English is not the same': challenges in thesis writing for second language speakers of English. Teaching in Higher Education 17 (3):283-293.

doi: 10.1080/13562517.2011.611871. 
Taylor, J. 2002. Changes in teaching and learning in the period to 2005: The case of postgraduate higher education. Higher Education Policy and Management 24:53-73.

Thompson, D.R., Kirkman, S., Watson, R., \& Stewart, S. 2005. Improving research supervision in nursing. Nurse Education Today 25 (4): 283-290.

doi: http://dx.doi.org/10.1016/j.nedt.2005.01.011

Unwin, T. 2007. Reflections on supervising distance-based PhD students. http://www.gg.rhul.ac.uk/ict4d/distance-based PhDs.pdf.

Van Laren, L., Pithouse-Morgan, K., Chisanga, T., Harrison, L., Meyiwa, T., Muthukrishna, N. \& Naicker, I. 2014. 'Walking our talk': Exploring supervision of postgraduate self-study research through methaphor drawing. South African Journal of Higher Education 28 (2): 639-659.

Van Vuuren, L. 2013. Strategieë om die studieleiding van nagraadse studente in die skool vir verpleegkunde aan die Universiteit van die Vrystaat te bevorder. Thesis for Magister Societatis Scientiae (Nursing) degree.

Wang, T. \& Li, L.Y. 2011. "Tell me what to do" vs "guide me through it': feedback experiences of international doctoral students. Active Learning in Higher Education 12 (2): 101-188.

Watts, J. H. 2010. Team supervision of the doctorate: managing roles, relationships and contradictions. Teaching in Higher Education. 15 (3): 335-339.

doi: 10.1080/13562511003740908.

White, T., \& Coetzee, E. 2014. Postgraduate supervision: E-mail as an alternative. Africa Education Review 11 (4): 658-673. doi: 10.1080/18146627.2014.935010.

Winberg, S. 2014. Changing our ways of supervising part-time postgraduates using an online supervision framework. http://www.iced2014.se/proceedings/1090 Winberg.pdf

Wisker, G. 2005. The good supervisor: Supervising postgraduate and undergraduate research for doctoral theses and dissertations. Basingstoke: Palgrave Macmillan.

Wolff, L. 2010. Learning through writing: reconceptualising the research supervision process. International Journal of Teaching and Learning in Higher Education 22 (1): 229-237. 